\title{
FUTEBOL E ESTÉTICA
}

Arlei Sander Damo

Professor do Departamento de Ciências Humanas da Universidade de Santa Cruz do Sul

\begin{abstract}
Resumo: Este ensaio pretende dar uma contribuição ao entendimento do esporte e, particularmente, do futebol no Brasil a partir de uma perspectiva estética. Desta forma são apresentadas e discutidas três categorias analíticas: o ritual disjuntivo, o "pertencimento" clubístico e a noção de jogo absorvente.

Palavras-chave: cultura; futebol; estética.
\end{abstract}

$\mathrm{O}$ gosto pelo futebol resistiu à crítica de esquerda, acadêmica ou não, à apropriação pela direita, especialmente pelas ditaduras, e até se constituiu, de 1970 para cá, em uma ocupação profissional e em um segmento em expansão da economia de mercado. $\mathrm{Na}$ América Latina, onde o futebol foi usado pela propaganda dos regimes antidemocráticos, justificando, em grande parte, o "denuncismo" esquerdista, o interesse por ele não diminuiu com o descrédito dos ditadores. Segue sendo a "religião leiga da classe operária", como afirmou Hobsbawm há tempos. Isso vale inclusive para a Europa, "berço da civilização esportiva", de onde surgiram também os hooligans, em meados dos anos 70. Na África e na Ásia, os esportes modernos ${ }^{1}$ eram pouco difundidos até meados do século XX. Houve, de lá para cá, um despertar generalizado, mais intenso, em que os conflitos étnicos são menores ou há mais abertura para o ocidente, respectivamente. $^{2}$

Diante desse cenário era preciso que as ciências humanas repensassem suas convicções, uma vez que, até bem pouco tempo, desdenhara o esporte, considerando-o um "tema menor" (Guedes, 2000; Leite Lopes, 1995). Nas duas últimas décadas - e, na América Latina, nos anos 90 - as ciências humanas foram superando os preconceitos e tratando o esporte, o lazer e o tempo livre com a mesma seriedade com que trata os temas clássicos (Alabarces, 2000).
Atualmente, o esforço de quem pesquisa e escreve sobre os esportes está dirigido para a compreensão e superação de certas perspectivas analíticas já esboçadas sobre o tema. Por isso mesmo, o que foi dito contra o esporte pelos intelectuais de esquerda, fundamentados nas várias correntes marxistas - que o esporte era uma ferramenta ideológica da propaganda anti-democrática, que promovia a coesão interclasses e amenizava o enfrentamento entre patrões e empregados, que tinha paralelos com o nacionalismo, etc. ${ }^{3}-$, não pode ser tomado como algo apenas despropositado. $\mathrm{O}$ que se tenta fazer na atualidade é compreender a crítica ao esporte, por vezes transformada em militância anti-esportiva, como uma leitura possível da realidade, diversa, por exemplo, daquela feita por grande parte dos próprios operários. ${ }^{4}$ Observa-se, então, que as conjecturas anti-esportivas dos intelectuais de esquerda eram uma reprodução muita próxima dos discursos dos sindicalistas da primeira metade do século XX. O componente político sobrepunha-se, em ambos os casos, ao componente heurístico. Na verdade, não se pretendia compreender o esporte e nem mesmo as razões pelas quais as classes trabalhadoras lhe tinham tanto apreço, mas denunciar o seu uso pelo Estado e pela burguesia (Oliven e Damo, 2001).

A perspectiva funcionalista também tem recebido críticas. Circunscrevendo o futebol ao esporte e o esporte ao campo do lazer e do entretenimento, os funcionalistas ten- 
dem a destacar o caráter compensatório das práticas em questão. Diferentemente da rotina previsível e racionalizada do mundo do trabalho ou da vida doméstica, os esportes constituiriam um espaço-tempo no qual seria possível vivenciar sentimentos agradáveis, de grande excitação, necessários à renovação das tensões essenciais à saúde mental. "O caráter essencial do seu efeito catártico é a restauração do tônus mental normal através de uma perturbação temporária e passageira da excitação agradável" (Elias e Dunning, 1992:137-38). O problema das incursões funcionalistas é o seu caráter universalisante, ${ }^{5} \mathrm{a}$ partir do qual o significado de uma prática social é substantivado, como equivalente para todos os indivíduos ou grupos que dela se apropriam. Se, por um lado, evidencia-se a totalidade do fenômeno, por outro, perde-se de vista as particularidades locais e as variações diacrônicas. Ainda que o esporte possa ter um componente catártico - desde Aristóteles esta explicação é evocada e restaurador, a maneira como foi apropriado, por diferentes grupos em contextos históricos e sociais igualmente distintos, demonstra que as suas "funções" pouco têm de essenciais, tendo seu significado variado consideravelmente.

Também existem as investidas metafóricas a partir das quais os esportes tendem a ser relacionados com outras instituições, sendo seu significado imposto de fora para dentro. Ou, como diria Gumbrecht (2001), os esportes passam a ser interpretados como qualquer coisa diferente do que realmente são. O problema aqui não é propriamente a recorrência a metáforas, mas certos vínculos forçados, até mesmo grosseiros, desconsiderando as especificidades de um e outro campo. No caso do Brasil, por exemplo, dizse que a popularidade do futebol deve-se, em grande medida, ao fato de, por ser praticado com os pés e, portanto, ser menos preciso do que aqueles praticados com as mãos - sobre as quais recai um extenso aprendizado e, por extensão, um domínio cultural - seu êxito e fracasso estarem sujeitos a explicações de ordem mágica - porque os pés são pouco treinados, estando sob o domínio da natureza -, dos componentes contingenciais tais como sorte, azar e assim por diante. Ao contrário, nos esportes praticados com as mãos raramente se pensa em infortúnios, mas em ineficácia. Em outras palavras, os esportes praticados com as mãos seriam aceitos mais facilmente em contextos nos quais prevalece uma base racionalista - mas democracias consolidadas -, ao passo que o futebol combinaria melhor com sociedades em que o pensamento mágico ainda possua um apelo significativo. Sendo o Brasil pen- sado a meio caminho entre o tradicional (mágico) e o moderno (racional), o futebol teria entre nós grande aceitação, de modo que a mesma base epistemológica serviria para explicar o êxito e o fracasso da nação e da seleção. O problema é como explicar, a partir dessa homologia, a popularidade do futebol na Europa.

Finalmente, há o pop-psicologismo de senso comum afirmando que os perdedores na vida se identificam com os vencedores no esporte. A questão aqui é saber se os vencedores na vida se identificam com os perdedores no esporte ou se a explicação só vale para o primeiro caso. De qualquer modo, seria difícil sustentar tal conjectura sabendo que no esporte também se perde - nada garante de antemão que o perdedor na vida vença no jogo - e, principalmente, de que nos esportes, e particularmente no futebol, existem regras de "pertencimento", pois perder e ganhar fazem parte da experiência de atletas e torcedores.

Descartadas as possibilidades criticadas acima, como e de que modo compreender o esporte e, particularmente, o futebol? Uma delas, sem dúvida, passa pelo reconhecimento da especificidade do campo esportivo, no interior do qual o futebol está situado. Essa proposta explicitaria a maneira como as preferências esportivas estão distribuídas em diferentes contextos. Também informaria os princípios que norteiam tais escolhas e a relação delas com outros valores e atitudes - políticos, religiosos, econômicos, etc. Teríamos então um amplo espectro sociológico das afinidades esportivas, mas nos faltaria, ainda, entender o esporte em sua especificidade. Isso não significa que ele tenha uma essência, igual em toda parte, mas que existe, em toda parte, algo que não pode ser reduzido a outra coisa; que lhe é próprio.

Pensar sobre esta questão, "por que gostamos de esportes", requer, como sugere Gumbrecht, em recente publicação do Caderno Mais!, uma "rematada estética". "Levar esportes a sério como um fenômeno estético pode tornar conscientes a nós (...) os locais sociais da beleza. (...) É lícito dizer que não há outro fenômeno na cultura contemporânea que leve o prazer da beleza a mais gente do que os esportes. Se deixarmos de reconhecer esse fato é porque temos enormes dificuldades para separar a fruição da beleza dos rituais da 'cultura elevada' (2001:6)".

Mas talvez não seja uma estética formalista kantiana, nos moldes sugeridos por Gumbrecht, que possibilitará o avanço desejável. Para ele o ponto de partida para uma abordagem estética dos esportes "reside na incontroversa competência dos verdadeiros fãs de dizer se um jogo foi bonito ou feio - independente do placar final. Tal juízo 
será sempre ponto pacífico para quem aprecie o jogo, embora normalmente não sejam capazes de dizer com base em quais conceitos e critérios acham-no belo" (Gumbrecht, 2001:6).

A contrariedade em relação à perspectiva de Gumbrecht é, em grande medida, produto de um olhar diferenciado, desde um ponto de vista antropológico. Como não se trata de substituir um olhar por outro - o da filosofia e da crítica literária pelo antropológico - e sim de complementálo, não se pode destacar a análise de Gumbrecht em sua totalidade. Mas oferecer às definições precedentes pontos de vistas divergentes. A primeira questão diz respeito à presumível independência entre o juízo estético e o resultado do jogo. A segunda sugere a existência de "verdadeiros fãs" e de que estes não são capazes de expressar os critérios e conceitos que fundamentam seus juízos.

Concordando que o ponto de vista estético é essencial para se entender a razão pela qual os esportes em geral e o futebol em especial são apreciados intensamente pelo público, será apresentado, daqui por diante, um contraponto à visão de Gumbrecht. Parte-se, portanto, da hipósete que:

- o resultado do jogo é um componente importante não apenas para entender o juízo dos torcedores, senão para entender a própria lógica dos esportes, especialmente do futebol;

- em vez de verdadeiros - e falsos - torcedores, existem diferentes modalidades de vínculos entre torcedores e clubes e dos próprios torcedores entre si, às quais correspondem formas diferenciadas de expressar o sentimento de "pertencimento"; e, finalmente, que existem alguns critérios, bastante gerais, a partir dos quais se pode afirmar, segundo o comportamento dos torcedores, se um jogo é bom ou ruim - e nem tanto se é bonito ou feio;

- tratando-se do comportamento dos torcedores, na sua interação com a dinâmica do jogo, importa não apenas os juízos expressos verbalmente mas um conjunto de signos comportamentais que, observados por ocasião dos jogos, indicam se esse é ou não um jogo absorvente.

Compreender as categorias que tornam um embate denso e envolvente é a chave compreensiva do fenômeno esportivo. O objetivo deste ensaio é dar continuidade a um debate que está apenas sendo iniciado e que pode, dada a possibilidade abrangente que a interpretação estética proporciona, juntar muitas das contribuições recentes no campo dos estudos sobre os esportes. Para tanto, pretende-se destacar a importância de certas categorias analíticas tais como: ritual disjuntivo, "pertencimento" clubístico e jogo absorvente.

\section{O RITUAL DISJUNTIVO}

Existe nos meios esportivos e até fora deles uma desaprovação ao suposto aumento da competitividade e da violência. É difícil responder se essa constatação é procedente pela ausência de critérios objetivos. ${ }^{6}$ A tendência quase unânime, dos torcedores aos críticos, é concordar com a afirmação de que o futebol já não é mais o que fora, especialmente no caso brasileiro, em que, segundo dizem, era voltado para o espetáculo: dribles, fintas, toques de efeito e malabarismos diversos; e o gol sendo o produto, o acabamento natural, jamais o objetivo principal do embate, como teria se tornado na atualidade.

Essa visão romântica que evoca a "beleza do morto" é decorrente, em grande medida, do fato da mídia reproduzir um dado recorte do passado futebolístico, geralmente os gols e as jogadas de exceção. Assim, a memória das gerações mais jovens inclina-se a ser tendenciosa, uma vez que é influenciada pelo recorte operado pelos meios de comunicação. Os lances menos cotados, encontrões, pontapés e jogadas violentas são preteridos, o que pode produzir no público a impressão de que o futebol de outrora era o que as imagens mostram em vez de entender as imagens mostradas atualmente como uma seleção e, portanto, parte do que fora o futebol.

Os contra-exemplos à tese do futebol romântico são tantos que não vale a pena listá-los aqui. De qualquer modo deve-se afirmar, uma vez mais, não existirem dados objetivos capazes de apontar para um aumento da competitividade e nem mesmo da violência. Mais vulneráveis ainda são os encadeamentos (i)lógicos e as justificativas usadas para explicar a mudança de cenário. O que se diz, em geral, é que o aumento da competitividade gerou o aumento da violência - dentro e fora de campo - e isso tudo devido ao incremento do capital econômico no esporte, cujos resultados passaram a interessar aos investidores em marketing e publicidade, sendo, então, sinônimos de lucro ou prejuízo. ${ }^{7}$ Os esportes, especialmente o futebol, seriam na atualidade a negação dos seus próprios ideais, dos seus valores originais, tornando-se uma atividade permeada por interesses difusos, enquanto outrora se caracterizaram pelo amadorismo e, portanto, pela disputa em outros parâmetros, normalmente vistos como acima dos interesses econômicos: no caso, pelo amor à agremiação e coisas do gênero. 
O aporte financeiro cresceu continuamente nas três últimas décadas trazendo mudanças significativas. Contudo, não alterou substancialmente a sua dinâmica estrutural. Se tomarmos Elias e Dunning (1992) como referência, veremos que os esportes evoluíram no sentido do controle e da restrição à violência física (e não em sentido contrário), mantendo, ainda, um grau variado de violência potencial, presente na própria estrutura do jogo. Em resumo, diria que a violência (física ou simbólica), os lucros (pecuniários ou não) e a competitividade estão prescritos pela estrutura do jogo e, fundamentalmente, o jogo não perde sua dimensão estética por apresentar tais componentes, como supõe a visão romântica.

Para entender melhor essa formulação é preciso retomar a comparação paradigmática entre ritual e jogo feita por Lévi-Strauss (1989). Os gahuku-gama, da Nova Guiné, jogam tantas partidas de futebol quantas forem necessárias até que o escore final de partidas ganhas e perdidas seja equivalente. Já os índios fox simulam um jogo entre mortos e vivos deixando os mortos vencerem para que seus espíritos, prestigiados com a vitória, permaneçam onde estão, sem admoestar os vivos. A maneira como nós, os ocidentais, encaramos os jogos é simetricamente oposta à maneira dos povos ditos primitivos. No jogo dos ocidentais, parte-se de uma situação de presumida equivalência entre as partes, reforçada pela existência de regras que devem ser respeitadas pelos contendores, para, ao final, produzir-se a assimetria, uma disjunção entre vencedores e vencidos. No jogo dos primitivos, as partes estão inicialmente em desequilíbrio, entre iniciados e não-iniciados, por exemplo, e ao fim são integradas sob uma mesma categoria. Enquanto no primeiro caso a simetria é estruturalmente pré-ordenada, a assimetria é engendrada pelos acontecimentos do jogo, por fatores tais como competência, preparo, sorte, etc. Daí porque o jogo é chamado de ritual disjuntivo. No correspondente inverso, o ritual conjuntivo, a performance consiste em fazer passar todos os participantes para o lado do ganhador, sendo o processo orientado para esta finalidade. $\mathrm{O}$ jogo, ou se se preferir, o ritual disjuntivo, produz acontecimentos, uma realidade inicialmente aberta embora limitada estruturalmente ganhar, perder e, em alguns poucos esportes, empatar-, mas de todo modo desconhecida até o final do evento.

Dessa comparação é importante reter duas premissas: o jogo possui uma estrutura, dita disjuntiva, que produz realidade, eventos/acontecimentos. Uma abordagem estética deve ter em conta essas premissas porque elas determinam uma certa perspectiva de encarar os jogos, uma sensibilidade que norteia a ação de atletas e torcedores, diferentemente do modo como atores e espectadores vivenciam o teatro, o cinema e o circo. Boa parte do interesse pelo espetáculo esportivo é dado pela expectativa em relação ao seu desfecho, à disjunção. Ainda que essa expectativa esteja presente em certos gêneros teatrais ou cinematográficos - no suspense, especialmente -, no caso dos esportes não existe um roteiro pré-definido, mas uma indeterminação completa, especialmente no caso dos contendores serem equiparados, o que é considerado como ideal. $^{8}$

A imprevisibilidade é um dos componentes centrais do espetáculo esportivo. Ela é responsável pela manutenção da tensão entre os atletas e, por extensão, entre os torcedores. Embora a indeterminação seja essencial ao bom espetáculo esportivo, este não se reduz a ela. Por isso a compreensão da estrutura é importante, porém insuficiente para se entender, por exemplo, porque alguns jogos são mais espetaculares do que outros tendo todos eles a mesma base estrutural. O placar final não traduz, em hipótese alguma, os desdobramentos da partida. A excitação proporcionada pelos esportes decorre, fundamentalmente, da experimentação das ambigüidades proporcionadas pelo desenrolar dos eventos próprios à sua dinâmica, cujos códigos são de domínio.

Um jogo raramente possui um desenvolvimento linear, tendendo a oscilações significativas que são o produto do enfrentamento e da disputa entre os contendores, razão pela qual cada gesto ou seqüência de movimentos tende a ser acompanhada com expectativa. É perceptível, no comportamento das torcidas, quando um jogo está empolgando ou não. Certamente não será quando os atletas trocam passes laterais, quando um atacante desperdiça todas as oportunidades de gol ou, ainda, quando uma das equipes tem sucesso em todas as investidas. Ao contrário do teatro, em que os atores ensaiam exaustivamente o roteiro para apresentá-lo o mais fiel possível, ${ }^{9}$ no esporte os atletas treinam para, a partir do domínio de certas técnicas elementares - chamadas de fundamentos -, improvisar durante o espetáculo, daí porque cada jogo é um jogo, dizem os torcedores. Enquanto Hamlet já foi não apenas reconstituído, mas adaptado segundo diferentes versões dos diretores, ainda não surgiu nenhuma adaptação da final da Copa de 50, exceto para o cinema, obviamente. ${ }^{10} \mathrm{~A}$ "tragédia do Maracanã" - derrota do selecionado brasileiro para o uruguaio por 2 a 1 - recebeu este epíteto por ser irreparável. O desfecho, naquele episódio, foi completamente diverso do esperado, foi um final surpreenden- 
te. As discussões enunciadas no condicional - "se Bigode tivesse barrado Ghiggia" ou "se Barbosa estivesse atento" e assim por diante - dão a clara idéia de que existe algo irredutível, próprio de um acontecimento, intangível a reprodução (Perdigão, 1986).

Em nossa cultura o espetáculo esportivo está assentado sobre uma dinâmica de forças oponentes, na qual o êxito de uma das partes implica o fracasso da outra. Não há síntese possível entre o bandido e o mocinho e, portanto, o confronto entre eles não gera um evento único, um filme tal ou qual. Para os torcedores é a vitória/derrota do seu time que lhes importa sobremaneira e boa parte dos juízos estéticos - que definirão se um jogo foi bom ou ruim, mais do que se foi bonito ou feio - repousa sobre esta variante. Isso não significa que eles se importem apenas com isso, mas o resultado do jogo influencia de tal modo a sensibilidade que acaba se tornando determinante.

De um atleta ou da equipe pela qual se torce não se esperam apenas gestos tecnicamente bem executados, cuja beleza possa ser contemplada em si mesma, mas uma certa eficácia. Cada movimento necessita produzir uma vantagem técnica sobre os adversários e isto configura uma relação de poder. O drible de Garrincha era repetitivo, esperado - desequilibrando o adversário com um jogo de negadas e saindo sempre para o lado direito. Seu êxito representava a humilhação do adversário incapaz de contêlo, numa inequívoca demonstração de poder, de violência simbólica; um raro espetáculo de supremacia para o deleite de botafoguenses e brasileiros. Apenas uns poucos torcedores e, particularmente, os críticos do esporte, possuem ou imaginam possuir a distância necessária para assistir um jogo sem se prender aos ímpetos de euforia e ira provocados por lances como o drible de Garrincha. Os torcedores, ou a maior parte deles ao menos, não assistem aos jogos para formular juízos imparciais - o que requer certo distanciamento -, mas antes para vivenciá-los.

Além do espetáculo decorrente do êxito de determinado gesto ou de uma sequiência deles, também há um prazer estético invisível, fruto da tensão originada pelo desenlace imprevisível que cada jogada proporciona. O gol - goal no original, significando meta, objetivo - é um desfecho possível e pode proporcionar aos espectadores o prazer estético pela forma, quer dizer, pela execução primorosa, mas pode, simplesmente, proporcionar o mesmo êxtase em razão da importância que ele possui para o resultado final do enfrentamento ou pela expectativa criada em relação a ele. Isso tudo, é claro, depende ainda de quem seja observador. Para uns, o gol é o coroamento bem-su- cedido de uma longa espera, para outros ele representa um triste episódio que significa a morte.

"Nenhum torcedor diria que se 'entretém' com seu time, que vai ver um jogo como vai a um concerto. Vai para dilacerar ou ser dilacerado, vai para a guerra, mesmo que seja quase sempre uma guerra metafórica. Assim, para ser atraente, o esporte não pode ter nenhum dos atrativos do espetáculo, nenhuma sugestão de montagem ou faz-deconta. Tem de ser uma séria e quase trágica competição por um cetro (...), a busca do coração do inimigo e da glória eterna - mesmo que no ano seguinte todos voltem a ter zero ponto" (Veríssimo, 1996).

Parte da estética esportiva não está ao alcance de quem observa apenas a forma. Desse ponto de vista o futebol mais parece uma seqüência de lances inócuos, repetitivos e sem sentido; com a bola sendo conduzida de uma intermediária a outra. Trata-se do ponto de vista daqueles que não têm familiaridade com as regras, com o significado do embate, enfim, com o próprio futebol. O prazer estético depende do entendimento da dinâmica do jogo, o que pressupõe aprendizado e, de outra parte, concordância em relação a alguns significados. Um desses significados partilhados pelos futebolistas é que o jogo é uma guerra mimética. Talvez este seja um dos paradoxos do esporte; ele é uma guerra, mas apenas simulada, é um faz-de-conta, e nisto se parece com o teatro. De outra parte, ele não pode parecer uma montagem premeditada, o suspense deve produzir-se ao longo do próprio espetáculo, sendo, portanto, um acontecimento. A compreensão do esporte na sua especificidade passa pelo reconhecimento desse paradoxo. Raros são os torcedores que vão ao estádio - nenhum, como sugere Veríssimo, é hiperbólico - para assistir ao seu time e muito menos para assistir a jogos em que seu time do coração não esteja envolvido. Vai-se aos jogos para torcer, empurrar o time ou, em certas circunstâncias, para protestar, por meio das vaias - a forma de participação política mais contundente no futebol. Os torcedores, de modo geral, têm uma atitude ativa, participando intensamente do espetáculo. Como diria Armando Nogueira, “(...) quando moço, do alto da arquibancada, nunca errei um passe e muito menos um chute. Cheguei a perder a conta dos gols que fiz com os pés que não foram meus" (Nogueira apud Toledo, 1994:25). ${ }^{11}$

Findo o ritual disjuntivo, os torcedores seguem o curso normal da vida. Visto sob esta perspectiva, o jogo mais parece uma fissura no tempo e, no caso dos que vão ao estádio, no espaço. Sendo assim, qual é o tipo de realidade produzida pelos esportes? É da ordem do simbólico, atua- 
lizando um intrincado jogo de símbolos associados aos chamados clubes do coração e ao gênero masculino. ${ }^{12}$ Além do prazer mimético, do faz-de-conta, próprio da brincadeira e da ludicidade, os jogos produzem acontecimentos que reverberam no interior do próprio campo esportivo. Apenas em circunstâncias especiais, como ocorre por ocasião de eventos como a Olimpíada, a Copa do Mundo ou uma final de certame nacional, os fatos esportivos avançam sobre a vida real. São raros os episódios em que o futebol, popularíssimo entre nós desde o início do século XX, produziu perturbações duradouras na política ou na economia nacional, vindo alterar o curso geral da Nação.

\section{O PERTENCIMENTO CLUBÍSTICO}

O amor aos clubes é a mola propulsora dos esportes coletivos, especialmente do futebol. ${ }^{13}$ Ainda que tenhamos torcedores não-praticantes, é raro encontrar praticantes que não tenham seu clube do coração. Torcer por um clube de futebol é a chave para a entrada num universo dominado pelo movimento e pela prática corporal, requisito indispensável a qualquer esporte, mas que, ironicamente, discutir é mais importante do que praticar - mesmo que, em discussões mais acirradas, o praticante possa evocar sua experiência como dispositivo de autoridade. O domínio dos códigos futebolísticos garante o acesso a certas discussões que ocorrem em momentos de sociabilidade intensa. Essas discussões, normalmente circulares - pois não são jamais conclusivas - e de natureza hipotética - pois os jogos são recriados, cada qual escalando seu time e fazendo-o atuar-, exigem dos envolvidos uma clara definição acerca da posição em que se encontram. Opina-se a partir de um referencial, como torcedor de uma dada agremiação, embora seja possível, evidentemente, discutir-se futebol em termos abstratos.

A escolha do clube do coração é realizada desde muito cedo, ocasião a partir da qual o indivíduo torna-se pessoa, passando a fazer parte de um mundo mais amplo que a casa e a família, o que lhe permite se definir e exercitar como parte de uma totalidade, vivida na rua, em pleno domínio público (Da Matta, 1994). A importância de se ter um clube para torcer pode ser dimensionada pela precocidade da escolha e pela sua extensão. Uma pesquisa sobre as marcas mais lembradas entre as crianças, a Top Kids,${ }^{14}$ realizada no Rio Grande do Sul em 1997, revelou um dado impressionante: nenhum(a) dos(as) entrevistados(as) se furtou à resposta quando perguntado(a) sobre qual o "time de futebol" que lembrava. O índice dos que "não sabiam" ou "não res- ponderam" foi zero, superando, inclusive, os itens: refrigerante, $4,7 \%$; chocolate, $7,3 \%$; e programa de TV, $8,7 \%$.

Como a escolha do clube do coração não é feita ao sabor das contingências, uma vez realizada não pode ser alterada facilmente, cabendo ao torcedor arcar com o ônus da sua opção. Trocar de clube, "virar a casaca", é uma falta gravíssima, podendo gerar suspeitas sobre a hombridade do sujeito. Como diz o hino do Flamengo, e isto vale para os demais clubes, "uma vez Flamengo, sempre Flamengo... Flamengo até morrer". Omitir ou mesmo encobrir a opção clubística é uma falta gravíssima e pode suscitar ameaças.

Recentemente, a Mancha Verde, do Palmeiras, distribuiu 50 mil cópias de um manifesto contra o narrador Galvão Bueno e a Rede Globo. Diferentemente da postura imparcial e isenta, pretendida e afirmada pelo narrador e pela emissora, o panfleto endereçado "à grande nação palmeirense" denunciava a suposta imparcialidade classificando a transmissão como "tendenciosa e desrespeitosa". Embora os cronistas esportivos procurem, via de regra, omitir sua predileção clubística para se manter eqüidistantes da ira torcedora, estes últimos tendem a enquadrá-los de acordo com critérios muitas vezes duvidosos. Segundo Dentinho, presidente da Gaviões da Fiel, "a gente prefere aqueles já declarados, que não escondem para que time torcem" (Folha de S.Paulo, 6/8/2000:12, TV Folha).

Em que pese o pertencimento ser vivenciado no domínio público, ele é indissociável das redes de sociabilidade próximas ao indivíduo, tais como família, vizinhos e amigos. ${ }^{15}$ Não por acaso se diz que os clubes são do coração, o topos corporal no qual se representam as emoções, e os distintivos dos clubes estão fixados do lado esquerdo do peito. A rede de sociabilidade responsável pela socialização primária e, portanto, pela inculcação de certas sensibilidades emocionais, permanece na lembrança dos torcedores. Exceto aqueles cuja escolha ocorreu muito cedo - isto é muito freqüente entre famílias de torcedores fanáticos, cujo "pertencimento" a mesma agremiação remonta três e até quatro gerações, assemelhando-se a uma casta - ou outros, cuja importância dada ao futebol é mínima, os demais geralmente lembram com detalhes o momento em que se tornaram palmeirenses, atleticanos ou vascaínos. Como não se trata de uma escolha de natureza ideológica, embora política, os processos de convencimento são travados na esfera das emoções e o "sim" normalmente é ritualizado: por ocasião de um presente, de um autógrafo e da ida ao estádio. 
O "pertencimento" também é único, embora seja comum certos torcedores realizarem escolhas em segundo grau de importância. ${ }^{16} \mathrm{~A}$ fidelidade ao clube contraria frontalmente a tese do pop-psicologismo, segundo a qual os perdedores na vida se identificam com os vencedores no esporte. De mais a mais, a escolha depende muito indiretamente da performance da equipe. Claro que é difícil convencer uma criança ou um adolescente a tornar-se botafoguense, fluminense ou colorado nos dias atuais, quando estes clubes repetem desempenhos medíocres. Todavia não basta que um clube esteja exposto na mídia, que vença vários campeonatos, para angariar adesões. Elas devem ser compassadas pela rede de sociabilidade, uma espécie de militância especialmente desperta quando o clube está em evidência.

Torcer por um clube de futebol é uma atitude política, como escreveu o poeta Drummond: "A estética do torcedor é inconsciente: ele ama o belo através de movimentos conjugados, astuciosos e viris, que lhe produzem uma sublime euforia, mas se lhe perguntam o que sente, exprimirá antes uma emoção política. Somos fluminenses ou vascos pela necessidade de optar, como somos liberais, socialistas ou reacionários" (Revista do Grêmio, s.d.:44).

O "pertencimento" clubístico é uma máscara social, uma das tantas existentes nas sociedades complexas. A partir dela se tem acesso a um universo no qual a brincadeira e a jocosidade são essenciais, pois é por intermédio delas que se expressam sentimentos e pontos de vista, não raro preconceituosos, que dificilmente seriam ditos de outro modo e em outro lugar. A máscara clubística, quando vivenciada coletivamente, em espaços públicos, estabelece o anonimato individual (Toledo, 1996). Assim, podese xingar a polícia, os torcedores adversários e os atletas e dirigentes do próprio clube.

Torcer é uma forma de participação política bastante peculiar. Abordar o "pertencimento" e as atitudes decorrentes deste vínculo desde o ponto de vista estético implica reconhecer nas manifestações dos torcedores - das falas, gestos, vestuário, etc. - certas mensagens cuja decifração, em termos de forma e conteúdo, permite-nos acessar alguns conflitos subjacentes à dinâmica social. Ou seria mero casuísmo o fato de os clubes de futebol no Brasil estarem, via de regra, identificados em pares de contrários do tipo elite/popular, branco/negro, centro/periferia, grande/pequeno, entre outros?

Por tudo isso, a estética futebolística brasileira, um caso particular da estética esportiva, é algo que a perspectiva formalista não pode captar. Há um sentido profundo nos embates, um pano de fundo cultural no qual os sentimentos de pertença e o próprio gosto pelo futebol estão alicerçados. O caráter democrático - em contrapartida ao autoritarismo e ao conservadorismo dos cartolas que manipulam as regras - torna cada torcedor um comentador, um crítico autorizado para falar em estilos de jogo e associá-los a certas categorias sociais. $\mathrm{O}$ futebol-arte revelaria o caráter do carioca, o futebol-força, a maneira como são os gaúchos e assim por diante (Damo, 1999). Se existe um campo no qual a autoridade dos críticos tem de ser permanentemente afirmada, e a duras penas, este campo é o do futebol.

\section{UM JOGO ABSORVENTE}

O futebol é um ritual performático que, assim como os demais esportes, põe em ação diferentes atores sociais e pode ser interpretado desde o ponto de vista da atuação de atletas, torcedores, mídias, cartolas, etc. Sendo uma prática corporal, revela, pela arte de jogar - do uso de técnicas específicas e do treinamento para produzir a eficácia - diferentes estilos que variam no tempo e no espaço. Como é um fato social de grande apelo popular, informa os gostos e os interesses do seu público, os parâmetros éticos e estéticos que orientam o comportamento individual e coletivo dos aficcionados. Todavia, nem todos os espetáculos futebolísticos despertam o interesse e boa parte deles tem-se realizado sem a presença de público nas arquibancadas. A pergunta é um tanto óbvia, mas não pode ser desdenhada: afinal, o que vem a ser um bom jogo de futebol, aquele que desperta o interesse do público?

A idéia de jogo absorvente é retirada de um texto clássico em Antropologia, sobre a Briga de galos em Bali (Geertz, 1989), mas não se pretende aqui estabelecer analogias entre os fatos sociais. Entretanto, seguindo a chave hermenêutica geertziana, pode-se dizer que compreenderemos algo sobre a cultura brasileira - dos homens, especialmente - observando o comportamento em torno do campo, da mesma forma que se observa a rinha de galos em Bali. Para tanto é necessário aprender certos códigos do embate, como é o caso das regras e das apostas, e saber diferenciar um galo bom da sua imitação, coisa que apenas os iniciados estão aptos. Finalmente, é preciso saber que os homens não fazem suas apostas pensando apenas no lucro pecuniário que poderão obter, mas respeitando certos códigos sociais. O jogo absorvente é aquele que põe frente a frente galos (atletas) de boa linhagem e seus donos de status elevado (clubes 
tradicionais). O risco e a excitação decorrem dessa combinação.

No futebol brasileiro as rivalidades entre as torcidas são causadas pelas rivalidades existentes entre os clubes. Em linhas gerais, as torcidas atualizam certas querelas que fazem parte da história das agremiações, boa parte delas circunscrita à própria origem dos clubes. Por isso os enfrentamentos mais densos são aqueles envolvendo clubes da mesma cidade, cujas rivalidades foram forjadas ainda nos tempos do amadorismo - antes dos anos 30.

As identidades clubísticas são contrastivas, de modo que o "pertencimento" não se esgota no amor ao clube do coração, mas na aversão por outro, o seu contrário. As rivalidades estão associadas a categorias mais amplas da sociedade e giram em torno de sentimentos vinculados a "grupos primordiais, aqueles em que nascemos, quer se concentrem na língua, costume, religião, raça, tribo, etnia ou lugar" (Lever, 1983:26). Cria-se, então, em torno dos clubes de futebol, extensas comunidades imaginárias de sentimentos (Souza, 1996:45).

Já os torcedores de um mesmo clube pensam-se a partir de uma lógica segmentar. As torcidas organizadas, por exemplo, estão permanentemente lutando por espaço e visibilidade diante dos demais torcedores, dos quais se diferenciam pela forma e intensidade de pertença. Os membros dessas torcidas acreditam demonstrar seu amor ao clube com um tipo de envolvimento militante, como se fossem um exército incumbido de defender verbal e fisicamente, se preciso for, a honra da nação-clube de futebol, podendo se envolver em atos violentos, tidos como heróicos. As hostilidades não se limitam aos torcedores dos "outros" clubes. Há divergências fortíssimas mesmo entre as torcidas organizadas de um mesmo clube. $\mathrm{Na}$ medida em que certas marcas diacríticas vão perdendo sua capacidade de distinção, outras tantas tendem a ser inventadas. Essas segmentações de natureza estrutural podem ser ilimitadas, mobilizando códigos e "pertencimentos" até certo ponto aleatórios - de bairro, colégio, gosto musical, e outras tantas afinidades exógenas ao clube do coração e ao futebol. ${ }^{17}$

A cada jogo e mesmo no espaço do cotidiano essas pertenças segmentadas são afirmadas e reafirmadas das mais variadas formas, dependendo, é claro, da posição e da intensidade com que cada torcedor vivencia o futebol. Os jogos que se sucedem uns aos outros, ano após ano, numa temporalidade cíclica, vão atualizando e reordenando as relações de pertença. Assim, "cada jogo é um jogo", e a cada evento são "jogados" - do ponto de vista dos tor- cedores - códigos, valores e atitudes de acordo com a peculiaridade dos clubes envolvidos no confronto. A trajetória pregressa de cada um deles, do confronto entre eles e as implicações mais imediatas que o resultado do embate pode acarretar, constituem os elementos mais significativos de um jogo.

De um lado há os 90 minutos de jogo, do ritual disjuntivo propriamente dito. Nele destaca-se a tensão decorrente do risco que o embate enseja, tanto maior quanto mais densa a rivalidade entre os clubes e os desdobramentos que o resultado pode acarretar. O gol é um evento raro, inserido noutro, que é o jogo, e como tal estabelece uma ruptura decorrente da densidade do seu significado. "Esse é o ritmo próprio do futebol: muitas ameaças, poucos gols. (...) Há poucos prazeres comparáveis ao de pular e gritar com a multidão, comemorando um gol que passa a ser de todos, por direito de contigüidade emocional" (Prado, 1997:213). O tempo do gol é um tempo espesso, vertical, marcado mais pela sua riqueza e densidade e menos pela duração. Daí existe uma dimensão estética que só pode ser apreendida se contextualizada, o que implica observar a sua forma - a sequiência de lances propriamente dita, à qual correspondem certos comportamentos dos torcedores - e também o seu significado.

De outro lado existem a história, a tradição e a memória. São o resultado de sobreposições e arranjos múltiplos produzidos pelos vários segmentos que constituem o universo futebolístico, num tempo e espaço que não é o do jogo propriamente dito. É o tempo do cotidiano, ligado ao espaço da casa e da rua, do trabalho e do lazer, em que se "discute futebol". Nesse espaço-tempo é que circulam as anedotas, as informações, as lembranças, os mitos, enfim, no qual se aproximam futebol e sociedade, dando a este esporte um encadeamento com outras esferas do social e aos agentes sociais - por intermédio daqueles que se dizem torcedores - uma sociabilidade vivida de modo particularíssimo, como um "faz-de-conta".

Uma partida de futebol pode ser apreciada simplesmente pelo espetáculo que os jogadores proporcionam. Mas será mais espetacular ainda se puder identificar a trajetória dos atletas, a importância do jogo e a história dos clubes. Todavia, será plenamente espetacular para aqueles cujos jogadores e clubes pertencem. Um jogo poderá ser excitante mesmo que tecnicamente fraco, basta que a tradição lhe assegure uma posição de destaque, denominando-o "clássico". E o inverso também é verdadeiro. Mas quando um jogo é denso de ambos os pontos de vista, do 
ritual disjuntivo e da tradição, é que ele pode ser dito absorvente; "inesquecível", como dizem os torcedores.

\section{ARREMATE}

O significado do futebol não poder ser condensado em um conceito fechado, definitivo, substantivado. O ritual disjuntivo, o "pertencimento" clubístico e o jogo absorvente são categorias que nos permitem chegar ao gosto dos torcedores, incursionando sobre os valores éticos e estéticos que orientam esta modalidade de participação na vida pública das sociedades contemporâneas. $\mathrm{O}$ futebol e os demais esportes não devem ser entendidos como meros negócios manipulados pelas grandes corporações multinacionais, mas também não se pode ignorar a influência delas. Sendo um fato social relativamente recente, exige, para a sua compreensão, um longo trabalho de pesquisa empírica aliado à ousadia teórica.

A hipótese de que os eventos esportivos produzem acontecimentos está indissociada da idéia de que boa parte deles são consumidos no próprio meio. E, fundamentalmente, à idéia de que consumir implica "destruir, gastar, desperdiçar, esgotar" (Featherstone, 1995:41). Uma estética do esporte, do futebol especialmente, deve incorporar as noções de excesso, de desperdício e de desordem: do excesso de significado de certos eventos (como o gol, por exemplo), do desperdício de dinheiro (empenhado para freqüentar os espetáculos e adquirir objetos ligados ao clube do coração), da ordem alterada nas cidades por ocasião dos jogos e das comemorações tresloucadas (festas, bebedeiras, violência, etc).

Mas o futebol também tem ordem, expressa pela estrutura ritual, pela lógica do "pertencimento" e pela densidade dos embates. Há ainda a hierarquização dos espaços nos estádios, segmentadores do público, e a diferenciação do consumo de imagens e produtos de acordo com as possibilidades socioeconômicas. A carnavalização dos espetáculos contrapõe-se ao padrão que está sendo implementado nos estádios modernos: cada torcedor ocupando seu lugar, de preferência numerado, preservando sua individualidade. As sensibilidades, o modo de torcer, de protestar, de comemorar o gol, são atitudes que estão em permanente processo de mudança e é preciso captá-las.

\section{NOTAS}

Agradeço a presteza de Patrice Schuch pelas valiosas críticas e sugestões às versões preliminares.
1. Aos leitores menos familiarizados com a literatura esportiva, convém esclarecer que o termo "esportes modernos" abarca um conjunto extenso de práticas corporais competitivas, regradas, individuais ou coletivas, praticadas por amadores ou profissionais, inventadas a partir da segunda metade do século passado nos internatos para jovens da elite européia, notadamente entre as public schools inglesas. Os esportes modernos diferenciam-se dos jogos tradicionais praticados na Renascença e na Idade Média pelo incremento das regras, visando, em última instância, reduzir a violência física e manter a violência simbólica (Bourdieu, 1983; Elias e Dunning, 1992; Leite Lopes, 1995). Nessa perspectiva o futebol deve ser compreendido como um esporte moderno, em que pese ele tenha assumido tamanha importância entre nós, que transcende o campo esportivo ou das práticas corporais.

2. Na ocidentalização do Oriente e orientalização do Ocidente os esportes ocupam um lugar de destaque. Uma prova disso é a grande quantidade de eventos esportivos internacionais realizados em países asiáticos com sucesso de público, uma das razões pelas quais a Copa de 2002 será sediada por Japão e Coréia do Sul. De outra parte, práticas marciais como o judô, o caratê, o kung-fu e outras, acabaram se esportivizando - transformando-se em competição - e se popularizando no Ocidente. Em relação à África é crescente a participação bem-sucedida de seus atletas no atletismo - especialmente em provas de resistência - e também no futebol, tendo-se tornado nas duas últimas décadas o grande celeiro do futebol europeu, juntamente com a América Latina.

3. A bibliografia que empregou as noções marxistas e frankfurtianas - tais como alienação, massificação, etc. - para explicar o fenômeno esportivo é bastante extensa. Como exemplo, Brohm (1972), Sebreli (1981) e Ramos (1984).

4. Sobre a tentativa de apropriação do futebol por parte dos sindicalistas e da resistência a ela por parte dos operários ver Antunes (1994).

5. Esta é uma crítica ao funcionalismo em geral, não apenas a sua explicação do esporte, e a todas as suas matizes, não apenas à Escola Britânica, de Malinowski a Radcliff-Browm. Em relação a Norbert Elias é oportuno explicitar que o viés funcionalista de alguns dos seus postulados não compromete a totalidade de sua obra, especialmente de $A$ busca de excitação, escrita em parceria com Eric Dunning, e cujo aporte ao "tema menor do esporte" está acima de qualquer contestação. De qualquer modo, o seu processo civilizador de longa duração é mais apropriado para o entendimento da emergência dos esportes modernos - e apenas em parte para compreensão de sua diáspora -, ao passo que as suas investidas funcionalistas para explicar o gosto contemporâneo sugerem um reducionismo empobrecedor. Para mais apreciações críticas a Elias, ver Souza (1996).

6. Embora o aumento da competitividade e, por extensão, da violência, seja tido como obviedade, faltam argumentos consistentes capazes de demonstrar a assertiva. Para um exemplo da fragilidade dos argumentos mais recorrentes, sugere-se a leitura da resenha crítica de Lovisolo (1998) à tese de Mauro Betti - Violência em campo, dinheiro, mídia e transgressão às regras no futebol espetáculo -, cujas pretensões eram, justamente, dar a esta impressão leiga contornos científicos e, a partir deles, contrapor-se à maneira como o futebol vem sendo apropriado pela economia de mercado. (Como pesquisador, o autor deste artigo, Damo, tem a pretensão de suspender temporariamente seus juízos - francamente contrários aos supostos benefícios, anunciados pela mídia, acerca da mercantilização do futebol brasileiro - para apreciar as mudanças em curso na atual conjuntura do futebol. Creio ser necessária certa cautela para não contaminar as observações de campo, o entendimento que diferentes segmentos têm sobre a questão, com prejulgamentos.

7. Ora, o Ba-Gua, disputado pelo Grêmio Bagé e pelo Guarani da mesma cidade, na fronteira meridional do Rio Grande do Sul, nunca serviu à publicidade e por certo não é pelo valor econômico do enfrentamento que se explicam as peleias decorrentes do confronto entre os co-irmãos. De mais a mais, os pesquisadores na área do esporte têm a obrigação de estar atentos e saber distinguir o contexto e o significado da manipulação de valores e símbolos no campo esportivo. Se é fato que os torcedores se queixam de que os atletas são mercenários e não têm "amor à camisa", não é menos verdade que seguem devotos do clube semiprivatizado, como é o caso de quase todos os grandes clubes do futebol brasileiro. $\mathrm{O}$ aumento do aporte de recursos financeiros no esporte requer uma análise mais sutil do que aquela freqüentemente empreendida.

8. Esta é uma das razões pelas quais existem divisões hierárquicas em todos os esportes. No futebol, por exemplo, existe uma primeira divisão que separa amadores de profissionais e, entre estes, duas, três e até quatro segmentações que estabelecem, entre aqueles que pertencem a um mesmo estrato, uma certa eqüidade.

9. O suspense, o teatro de improviso ou realista, a performance circense, entre outros, se aproximam do jogo, mas são gêneros específicos dentro do cinema, do teatro e do circo. Para uma análise comparativa do simbolismo entre futebol e teatro cf. Soares (1979). 
10. Barbosa, curta-metragem de Jorge Furtado.

11. Veja-se o caso das torcidas organizadas. Elas têm um comportamento espetacular, atuando como conjuntos cênicos. São parte do espetáculo, com suas coreografias, gritos de guerra e xingamentos, despertando o interesse - admiração e medo - dos outros torcedores, até mesmo o do próprio clube e também da mídia. Especialmente aquelas tuteladas pelos clubes, como no caso do Rio Grande do Sul, seu comportamento é preestabelecido: ocupam sempre o mesmo espaço no estádio; têm certos cânticos para as diferentes circunstâncias do jogo e para os diferentes adversários; coreografias ensaiadas; enfim, delas se espera apoio ao time em qualquer circunstância, sendo-lhes vedada a vaia e o protesto. Não é esse o caso das torcidas organizadas independentemente do clube.

12. Tal qual a guerra, o futebol é um campo reservado, preponderantemente, ao gênero masculino. Essa reserva é obra da cultura inscrita no social - de modo que nos EUA, por exemplo, o soccer é praticado pelas mulheres em larga escala nada tendo a ver com limitações de ordem biológica, exceto para uns poucos preconceituosos. Trata-se de um campo do qual os meninos, que da prática se aproximam, e as meninas, que dela se afastam (atualmente com menos ímpeto, na medida em que as fronteiras de gênero tornaram-se mais porosas), percebem como sendo bom para se exercitar performances masculinas, tais como: confrontos físicos às vezes violentos, uso da força e dos pés, agressividade verbal por xingamentos, etc.

13. Até as empresas de marketing já se deram conta disso, como é caso da Hicks, Muse, Tate \& Furst, empresa norte-americana que investe em clubes, estádios, direitos de transmissão, redes de TV a cabo, entre outros. Segundo Charles Tate, representante da empresa no Brasil, "as pessoas estão interessadas no que acontece com o seu clube. $\mathrm{O}$ torcedor acompanha o time quando este participa de uma competição regional, o que vale também para um torneio internacional. Os torcedores querem ver seus times, mais do que suas seleções na Copa" (Revista Exame, 9/2/2000).

14. A pesquisa Top Kid é uma versão para crianças e adolescentes da Top of Mind. Elas captam a lembrança imediata dos entrevistados sobre marcas de produtos e serviços. Nesse tipo de pesquisa, o entrevistado é convidado a citar, a cada estímulo do entrevistador, o primeiro nome que lhe vem à cabeça. "Quando eu falo em (time/clube de futebol), que marca lhe vem à cabeça?" (Revista Amanhã, 1997)

15. A Pesquisa de Marketing Aplicado, desenvolvida pelos alunos da disciplina "Pesquisa de Marketing" da Escola de Administração da Universidade Federal do Rio Grande do Sul - realizada no segundo semestre de 1997 - revelou que a escolha do clube do coração ocorre até os 15 anos de idade em mais de $80 \%$ dos casos, sendo que quase a metade dos torcedores faz sua opção antes mesmo dos cinco anos de idade. A pesquisa também demonstra a importância da rede de sociabilidade mais intensa na definição do pertencimento. Em mais de $70 \%$ dos casos a escolha foi influenciada por alguém da família ou amigos próximos a ela.

16. É comum, por exemplo, o sujeito dizer-se corinthiano, mas no Rio Grande do Sul ser colorado, no Rio de Janeiro ser flamenguista e em Minas, atleticano e assim por diante. Um clube em cada região ou Estado e, o que é muito freqüente entre os políticos, um em cada cidade, preferencialmente o mais popular. No caso do torcedor hipotético (exemplificado acima), a lógica da escolha, a partir do Corinthians, tido como um clube popular, segue o mesmo padrão. Ou seja, torcese por todos os clubes tidos como populares. Existem, contudo, outros padrões de escolha como é o caso das cores dos uniformes - são-paulino, fluminense, gremista, bahiano, todos tricolores - mas os mais freqüentes no Brasil são os recortes de raça, classe social e região.

17. A segmentação "Nós, os gremistas" por oposição aos "outros", sejam eles pertencentes a outras "nações" ou simplesmente alheios às predileções clubísticas, perde sua eficácia distintiva no âmbito dos torcedores do Grêmio. Nem mesmo as diferenças entre "nós, das organizadas" e os "outros, que não são" são suficientes para demarcar a identidade desses grupos de torcedores. "Nós, da Raça", ao contrário "deles, da Jovem", é apenas mais uma segmentação, a rigor, seguida por "nós, da Raça que viajamos com o Grêmio" e os "outros, da Raça, que não viajam".

\section{REFERÊNCIAS BIBLIOGRÁFICAS}

ALABARCES, P. "Los estudios sobre deporte y sociedad: objetos, miradas, agendas". In: (org.). Peligro de gol. Buenos Aires, Clacso, 2000, p.11-30.

ANTUNES, F. "O futebol nas fábricas". Dossiê Futebol/Revista USP. São Paulo, n.22, 1994, p.102-09.

BOURDIEU, P. "Como é possível ser esportivo”. Questões de Sociologia. Rio de Janeiro, Marco Zero, 1983, p.136-53.

BROHM, J.-M. Deporte, cultura y represión - Colección Punto y Linea. Barcelona, Gustavo Gili, 1972.

DA MATTA, R. "Esporte na sociedade: um ensaio sobre o futebol brasileiro". In:_ (org.). Universo do futebol: esporte e sociedade brasileira. Rio de Janeiro, Pinakotheke, 1982, p.19-42.

. "Antropologia do óbvio". Dossiê Futebol/Revista USP. São Paulo, n.22, 1994, p.10-7.

DAMO, A. "Ah! Eu sou gaúcho! O nacional e o regional no futebol brasileiro." Estudos Históricos. Rio de Janeiro, FGV, v.13, n.23, 1999, p.87-117.

ELIAS, N. e DUNNING, E. A busca da excitação. Lisboa, Difel, 1992.

FEATHERSTONE, M. Cultura de consumo e pós-modernismo. São Paulo, Studio Nobel, 1995

GEERTZ, C. "Um jogo absorvente: notas sobre a briga de galos balinesa". In: ___ A interpretação das culturas. Rio de Janeiro, Guanabara, 1989, p.278-321.

GUEDES, S. "Malandros, caxias e estrangeiros no futebol: de heróis e anti-heróis. In: GOMES, L.; BARBOSA, L. e DRUMMOND, J. (orgs.). O Brasil não é para principiantes. Rio de Janeiro, Editora FGV, 2000, p.125-42.

GUMBRECHT, H.U. "A forma da violência: em louvor da beleza atlética". Folha de S.Paulo, 11/03/2001, Caderno Mais, p.6-9.

LEITE LOPES, J.S. "Esporte, emoção e conflito social". In: Mana - Estudos de Antropologia Social. Rio de Janeiro, Museu Nacional-Relumé/Dumarú, v.1, n.1, 1995, p.141-63.

LEVER, J. A loucura do futebol. Rio de Janeiro, Record, 1983.

LÉVI-STRAUSS, C. O pensamento selvagem. Campinas, Papirus, 1989.

LOVISOLO, H. "Futebol, mercantilização e violência". Motus Corporis. Rio de Janeiro, Gama Filho, v.5, n.2, nov. 1998, p.174-83.

OLIVEN, R. e DAMO, A. Fútbol y cultura. Buenos Aires, Norma, 2001.

PERDIGÃO, P. Anatomia de uma derrota. Porto Alegre, L\&PM, 1986.

PRADO, D. de A. Seres, coisas, lugares: do teatro ao futebol. São Paulo, Cia. das Letras, 1997.

REVISTA AMANHÃ. "As marcas do Rio Grande”. Porto Alegre, ano XI, n.118, abr. 1997.

REVISTA DO GRÊMIO. Porto Alegre, ano 2, n.11, s.d.

RAMOS, R. Futebol. Ideologia do poder. Rio de Janeiro, Vozes, 1984.

SEBRELI, J. Fútbol y masas. Buenos Aires, Galerna, 1981.

SOARES, L.E. "Futebol e teatro, notas para uma análise de estratégias simbólicas". Boletim do Museu Nacional. Rio de Janeiro, n.33, jun. 1979, p.1-23.

SOUZA, M. A 'Nação em chuteiras': raça e masculinidade no futebol brasileiro. Dissertação de Mestrado. Brasília, UnB, 1996.

TATE, C. Entrevista. Revista Exame, 9/2/2000.

TOLEDO, L.H. Torcidas organizadas de futebol. Dissertação de Mestrado. São Paulo, Programa de Pós-Graduação em Antropologia Social da USP, 1994. de Torcidas organizadas de futebol. São Paulo, Autores Associados/Anpocs, 1996.

VERÍSSIMO, L.F. "Um dilema”. Jornal do Brasil, 30/11/1996. 